Year:3, Volume:3, Number:5 / Yul:3, Cilt:3, Sayt:5/2019
$\begin{aligned} & \text { Theurnal of } \\ & \text { Social } \\ & \text { Science }\end{aligned}$

DOI Number: 10.30520/tjsosci.518144

\author{
TÜRKIYE MUHASEBE VE RAPORLAMA STANDARTLARININ \\ FINANSAL ANALIZE ETKİSI ${ }^{1}$ \\ THE EFFECTS OF TURKISH ACCOUNTING AND REPORTING STANDARDS ON \\ THE FINANCIAL ANALYSIS
}

Betül Şeyma ALKAN ${ }^{2}$

\begin{abstract}
ÖZET
Sermaye piyasalarının küreselleşmesi ve sermaye hareketlerinin hızlanmasıyla birlikte ülkelerarası finansal raporlama uygulamalarında tekdüzen ve ortak bir dil oluşturma zorunluluğu ortaya çıkmıştır. Uluslararası düzenlemelerdeki farklılıkları ortadan kaldırmak ve tüm bilgi kullanıcılarının ihtiyacını karşılamak amacıyla Uluslararası Muhasebe Standartları ve Uluslararas1 Finansal Raporlama Standartları yayınlanmıstır. Türkiye'de muhasebe ve finansal raporlama standartlarına göre hazırlanan finansal tablolar, vergi mevzuatına göre düzenlenen finansal tablolardan farklılık göstermektedir. Finansal raporlamanın çerçevesini oluşturan her iki düzenlemedeki değerleme ve sınıflandırma farkı şüphesiz ki finansal tabloların analizinde de önemli etkilere yol açacaktır. Bu çalışmada, Tek Düzen Hesap Planı'na (TDHP) göre düzenlenen finansal tablolar, düzeltme ve sinıflandırma kayıtları yapılarak, Türkiye Muhasebe ve Raporlama Standartlarına (TMS/TFRS) uygun hale getirilmiştir. TMS/TFRS'ye uyumlu finansal tablolara geçisin finansal analize etkisini tespit etmek amacıyla oran analizi yöntemi kullanılarak örnek bir uygulama sunulmuş ve farklılıklar karşılaştırmalı olarak incelenmiştir. Oranların, standart uygulamaları kapsamında yapılan hangi düzeltme kayıtları neticesinde farklılık gösterdiği tespit edilmeye çalışılmıştır.
\end{abstract}

Anahtar Kelimeler: Finansal Tablolar, TMS/TFRS, Oran Analizi

\footnotetext{
${ }^{1} \mathrm{Bu}$ çalışma, 29-31 Mart 2018 tarihlerinde düzenlenen 6.Uluslararası Çin'den Adriyatik'e Sosyal Bilimler Kongresi’nde sunulan bildirinin genişletilmiş halidir.

${ }^{2}$ Dr., betulalkann@gmail.com
} 


Year:3, Volume:3, Number:5 / Yul:3, Cilt:3, Sayt:5/2019

\begin{abstract}
The necessity of creating a uniform and common language in international financial reporting applications were arisen along with the globalization of capital markets and accelerated capital flows. International Accounting Standards and International Financial Reporting Standards were issued in order to eliminate the differences in international regulations and to meet the needs of all information users. In Turkey, the financial statements based on Turkish Accounting Standards and Turkish Reporting Standards (TAS/TFRS) differ from financial statements based on tax legislation. Valuation and classification difference in both regulation will lead to significant implications in the analysis of financial statements. In this study, financial statements based on Turkish Uniform Chart of Accounts are adjusted to TAS/TFRS by making correction and classification. In order to indicate the effect of transition to financial statements prepared in accordance with TAS/TFRS on the financial analysis, a case study is presented using the ratio analysis method, and the differences are examined comparatively. It is tried to explain that the ratios differ as a result of which adjustment records within scope of standard applications.
\end{abstract}

Keywords: Financial Statements, TAS/TFRS, Ratio Analysis

\title{
1. GİRiş
}

Küreselleşen dünyada her alanda olduğu gibi, yatırım ve sermaye piyasalarında da hızlı gelişimin bir sonucu olarak işletmelerin finansal tablolarının belirli standartlarda düzenlenmesi ve sunulması önem arz etmektedir. Uluslararası ticaretin gelişmesiyle birlikte işletmelerin farklı muhasebe uygulamalarına sahip olmaları, küresel platformda bu sistemleri birbiriyle yakınsama ve ortak bir muhasebe standartları seti gereksinimini ortaya koymuştur. Farklı muhasebe ilke ve kurallarına göre düzenlenen finansal tabloların bir sonucu olarak bilgi kullanıcıları, ilgili mali raporların yorumlanması ve analizi açısından da farklılıklarla karşılaşmaktadır. Böylece, farklı ülkelerin farklı muhasebe uygulamaları finansal bilgilerin karşılaştırılmasında tekdüzeni engellemektedir. $\mathrm{Bu}$ doğrultuda, ulusal ve uluslararası muhasebe uygulamlarını uyumlaştırmak, finansal raporlamada bir standardizasyon belirlemek ve genel kabul görmüş muhasebe ilkelerine uyumlu standartlar oluşturmak gereği doğmuştur.

Ulusal muhasebe uygulamalarını, küresel muhasebe uygulamalarına yakınsama çalışmaları Uluslararası Muhasebe Standartları Kurulu (IASB) ile sağlanmıştır. IASB, uluslararası muhasebe standartları düzenleme ve yayınlama otoritesi olarak genel kabul görmüş, bağımsız bir kuruldur. Kurul tarafından oluşturulan UMS ve UFRS'nın amacı, dünya üzerinde birçok ülke tarafindan kabul görmüş standart uygulamaları ile işletmelerin finansal durum ve performanslarının gerçeğe en uygun şekilde sunulmasını, bu doğrultuda finansal tabloların karşılaştırılabilir nitelikte olmasını sağlamaktır. Türkiye'de ise UMS ve UFRS'ler tümüyle tercüme edilerek dilimize çevrilmiş, TMS ve TFRS olarak düzenlenerek yayınlanmıştır. Standart uygulamaları ile birlikte, uluslararası sermaye piyasalarında girişimciye, ortak bir muhasebe standartları seti ile hazırlanmış finansal raporlar sağlanması amaçlanmaktadır.

Türkiye'de ise 6102 sayılı Türk Ticaret Kanunu hükümleri çerçevesinde finansal raporlamanın TMS/TFRS'na uygun olarak hazırlanması zorunlu kılınmıştır. Ancak ülkemizde muhasebe uygulamalarında halen vergi kanunu düzenlemelerinin önemli etkisi görülmektedir.Illke bazlı standartlar olan TMS/TFRS'ler, vergi uygulamalarından farklı olarak mali tabloların değerlenmesi ve sunulması açısından gerçeğe uygun değerlemeyi esas alan uygulamalardır. Böylece muhasebe anlayışını tümüyle 
değiştirmekte, özellikle finansal raporlama süreç ve sonuçlarını önemli ölçüde etkilemektedir.

İşletmeler, Muhasebe Sistemi Uygulama Genel Tebliği (MSUGT) uyarınca muhasebe sistemlerini Tek Düzen Hesap Planı(TDHP) çerçevesinde kurmakla yükümlüdür. Böylece işletmelerin VUK'a göre finansal tablolar düzenlemesinin yanı sıra uluslararası muhasebe ve raporlama standartları çerçevesinde de işlemlerini kayıt altına alma ve raporlama zorunluluğu doğmuştur. Muhasebe kayıt süreci, vergi kanunlarına göre hazırlanmış finansal tabloların, standartların ilke ve esasları çerçevesinde yeniden düzenlenerek bilgi kullanıcılarına sunulmasıyla tamamlanmaktadır. Ulusal ve uluslararası muhasebe kayıt sisteminde ki farklı uygulamalar nedeniyle, finansal tablolar üzerinde de çeşitli etkiler söz konusudur. Bu doğrultuda, TMS/TFRS uygulamalarının finansal tablolar üzerindeki etkisini incelemek önem arzeder. Standart uygulamaları dolaylı olarak sermaye piyasalarını önemli ölçüde etkilemekle birlikte finansal tablolardaki değişime doğrudan etkisi olmuştur. Ulusal düzenleme ve uluslararası standartlar kapsamındaki değerleme ve sınıflandırma farkı neticesinde finansal tablolardaki hesaplarda yapılan değişiklikler, işletmelerin finansal analizinde de önemli değişim ve farklılığa sebebiyet verecektir.

Finansal analiz, işletmenin mevcut finansal durumunu ve faaliyet sonuçlarını belirlemek ve gelecekteki finansal durum ve performansını tahmin etmek ve finansal kararlar alabilmek amacı ile finansal tablolarının incelenmesidir. Başka bir ifadeyle, finansal analiz, işletmenin geçmişe ait muhasebe bilgilerini finansal kararlarda kullanilabilecek işletmenin geleceğine ilişkin bilgilere dönüştürmektir. $\mathrm{Bu}$ doğrultuda, işletmelerin performans düzeyinin belirlenmesi, işletme faaliyetlerinin yürütülmesinde geleceğe yönelik adımların planlanması ve değerlendirilmesi konularına ilişkin karar alma sürecinde etkin bir yönetimin gerçekleşmesine hizmet eder.

$\mathrm{Bu}$ çalışmanın kapsamını oluşturan finansal analiz yöntemlerinden "Oran Analizi” ise finansal tablolarda yer alan hesap ve hesap grupları arasındaki ilişkinin ortaya konulmasını sağlar. Oran ilişkilerinden yararlanılarak bir işletmenin; likitide, finansal yapı, karlılık ve faaliyet etkinliği analiz edilebilir. Oran analizi sonuçlarının gerçeğe uygunluğunun sağlanması için oranların karşılaştırılması ve değerlendirilmesi gerekir. Finansal tablo kalemleri arasındaki ilişkiyi gösteren çok sayıda oran hesaplamak mümkündür. Çağdaş yazın, işlevleri açısından oranları dört sınıfa ayırmaktadır. İlgili oranlar; likitide oranları, finansal yapı oranları, faaliyet oranları ve karlılık oranlarıdır (Akdoğan ve Tenker, 1998:601).

Günümüzde muhasebe ve raporlama standartları kullanılarak finansal raporlar hazırlamak ne ölçüde önemliyse ilgili tabloların analiz edilerek doğru okunması da son derece önemlidir. Ulusal muhasebe literatürü incelendiğinde, TDHP-TFRS geçişli finansal tabloların hazırlanmasına ilişkin pek çok çalışma bulunmaktayen, standartların tablolar üzerinde etkileri finansal analiz açısından yeterli düzeyde ele alınmamıştır.

Uluslararası Muhasebe ve Raporlama Standartları ile uyumlu TMS ve TFRS'lerin uygulanması, işletmelerin finansal tablo verilerinden hesaplanacak olan oranlara ilişkin pay veya payda kısmında artış ya da azalış olarak birçok değişikliğe neden olacaktır. Hesap kalemlerindeki mutlak farkl1lık ve işlemin içeriğine göre, değişim büyüklüğü de farklılık gösterecektir. Standart uygulamaları neticesinde işlemin içeriğine bağlı olarak hesap kalemlerin belirli artış ya da azalış yönünde değişimler söz konusu olacaktır. 
Bunun en önemli göstergesi ise, TMS ve TFRS uygulamalarının finansal tabloları kesin surette etkilemiş olmasıdır. Ancak, etkinin yönü ve derecesi işletmelerin faaliyet gösterdiği sektör bazına ve dönem aralığına göre farklılık gösterebilir. Bu doğrultuda, finansal oranlar üzerindeki etki de zamana ve işletmeden işletmeye göre değişecektir.

Çalışmanın amacı; TDHP'na göre hazırlanan finansal tabloların TFRS'na göre düzeltme ve sinıflandırma kayıtları yapılarak hazırlanan TFRS Finansal tablolar ile arasındaki farklılıkların oran analizi yöntemiyle karşılaştırılması ve incelenmesinin örnek bir uygulama ile ele alınmasıdır. Her iki düzenlemenin oran analizine yansıması şüphesiz ki önemli farklılıklar gösterecektir. Muhasebe standartları uygulaması ile hangi hesapların yeniden değerleneceği ve nasıl sınıflandırılacağı, sınıflandırmada hangi hesapların kullanılmadığ1, hangi unsurların ertelenmiş vergi etkisi doğurduğu, bu doğrultuda düzenelenen TFRS tablolarına göre oran analizinde kullanılacak formüllerde hangi pay ve payda değerlerinin farklılaştığı ele alınması gereken konulardır. Düzeltme kayıtları ile birlikte değerleme ve sınıflandırma farklılıkları, ortaya çıkan mali tablolar ile de karşılaştırmalı olarak hesaplanan oranlardaki farklılıklar açıklanmıştır.

\section{LITERATÜR TARAMASI}

Ulusal ve uluslararası literatür incelendiğinde TMS/TFRS uygulamalarına ilişkin birçok ampirik çalışma yapılmakla birlikte, bu çalışmanın konusu dahilinde sadece finansal analize yönelik literatür taraması yapılmıştır. Ulusal literatür incelendiğinde, Türkiye Muhasebe Standartları'nın muhasebe uygulamaları ile vergi uygulamalarının karşılaştırılması, düzeltme kayıtları sonrası ertelenmiş verginin hesaplanması üzerine hazırlanmış çokça çalışma mevcuttur. Ancak standartlarla raporlamaya geçiş ile birlikte finansal analize etkileri konusunda pek az çalışmaya rastlanmaktadır.

Ağca ve Aktaş (2007) çalışmalarında, IMKB'de işlem gören, 5 farklı sektörden 147 şirketin, VUK'a göre düzenlenmiş mali tablolarını TFRS'ye göre düzenleyerek mali tablo farklılıklarının rasyo analizine etkilerini incelemişlerdir. Çalışmada 12 adet oran kullanılmış, ve düzenlenen mali tablolar arasında istatistiki olarak anlamlı farklılıklar olduğu sonucuna varmışlardır. VUK-TFRS dönüşümü neticesinde finansal rasyoların değişiklik gösterdiğini ve sektör bazında farklılıklar oluştuğunu tespit etmişlerdir.

Çelik, Aygören ve Uyar (2007), SPK'ya tabi işletmelerin TFRS ve vergi uygulamalarına göre hazırlanan mali tablolarının finansal rasyo sonuçlarında oluşan farklılıları istatistiksel anlamlılık açısından incelemiştir. Çalışma kapsamında 12 farklı oran kullanılmış ve özellikle uzun vadeli borçluluk oranında, borç-özsermaye oranında ve duran varlıklar/özsermaye oranlarında önemli değişimler olduğunu tespit etmişlerdir.

Ataman ve Özden (2009), uluslararası muhasebe standartlarının finansal tablolar üzerindeki etkilerini, rasyo analizi yöntemiyle incelemiştir. Çalışma sonucunda; muhasebe standartları kapsamında finansal tablo verilerinin değişikliğe uğradığı ve işletmenin gerçek finansal durum ve performansını yansıttığı gözlemlenmiştir. Standart gereği yapılan değer düşüklügü incelemelerinin işletmenin karlılık oranlarını değiştirdiği görülmüştür. TFRS mali tablolarında likitide ve karlılık oranlarının düştüğü, mali yapı ve faaliyet oranlarının ise yükseldiği tespit edilmiştir.

Atmaca (2010) çalışmasında, TMS/TFRS uygulamalarındaki değişimler ile finansal analiz ilişkisini incelemiştir. Çalışma kapsamında, TMS/TFRS'lerin yatırım amaçlı finansal analiz, yönetim amaçlı finansal analiz ve kredi amaçlı finansal analiz açısından 
değerlendirilmesi yapılmıștır. Standart uygulamalarının, finansal uyuşmazlıkların giderilmesinde, kredi değerliliğinin tespitinde, likite ve faaliyet oranlarında etkili olduğu tespit edilmiştir.

Bayır (2010) çalışmasında, TDHP'na ve TMS/TFRS'lere göre düzenlenen bilançoların karşılaştırmalı olarak analizlerini yapmış ve farklılıklarını irdelemiştir. Çalışma neticesinde, TDHP'na ve TMS/TFRS'lere göre düzenlenen mali tablolar arasinda biçimsel, kapsam ve içerik bakımından önemli farklılıklar olduğu tespit edilmiştir.

Elitaş (2010) çalışmasında, bir işletmenin finansal durumunu vergi uygulamaları ve standart uygulamaları açısından değerlendirmek üzere finansal oranlardan yararlanmıştır. Çalışma neticesinde, standart uygulamalarının, vergi mevzuatına göre finansal oranları mutlak değer ve oran olarak önemli düzeyde etkilemediğini, işletmeden işletmeye farklılık gösterdiğini ve de dönemler itibariyle farklılık göstereceği ortaya konulmuştur.

Balcı (2012), TFRS'lerin oran analizine etkilerini ölçmeye yönelik bir çalışma gerçekleştirmiştir. TFRS öncesi ve sonrası oran analizinde nasıl bir farklılaşma yaşandığı üzerine yürüttüğü çalışma sonucunda; TFRS'ye dönüşümle likidite ve kârlılık oranlarının düştügüu, finansal yapı ve faaliyet oranlarının ise yükseldiği tespit edilmiştir.

Büyükşalvarcı ve Uyar (2012), TMS ve TFRS uygulamaları ile farklı muhasebe düzenlemelerine göre hazırlanan finansal tablolardan elde edilen finansal oranlardaki farklılılıklar üzerine bir çalışma yürütmüş ve oluşan farkların hisse senedi getirileri üzerinde etkisi araştırılmıştır. Çalışma kapsamında, Borsa İstanbul'da imalat sektöründe faaliyet gösteren 91 adet işletmenin 2004 yılına ilişkin ve UFRS'ye göre hazırlanmış mali tablolardan elde edilen finansal oranları incelenmiştir. Çalışma neticesinde, UFRS'ye göre hazırlanmamış mali tablolardan elde edilen finansal oranların şirketlerin hisse senedi getirilerini ve piyasa değerlerini açıklamada daha üstün olduğu tespit edilmiștir.

Terzi, Öktem ve Şen (2013) çalışmalarında, TMS/TFRS'ye geçişin Borsa İstanbul'da imalat sanayinde faaliyet gösteren işletmeler üzerindeki etkisini araştırmıştır. Çalışma sonucunda, TDHP'na ve TMS ve TFRS'ye göre hazırlanan finansal tabloların istatistiksel olarak farklılıklarını tespit etmiştir. Anlamlı farklılıklar stoklar, duran varlıklar, uzun vadeli yabancı kaynaklar ve özsermaye hesaplarında belirlenmiştir. Ayrıca, cari oran, alacak devir hızı, varlık devir hızı, toplam yabancı kaynak/maddi duran varlıklar oranı, duran varlık devir hızı, özsermaye devir oranı, kısa vadeli yabanc1 kaynak/ toplam yabancı kaynak oranı ve kısa vadeli yabancı kaynak/toplam varlıklar oranı istatistiksel ve anlamlı olarak farklılık göstermektedir.

Yenigün ve Aydemir (2015), Türkiye Muhasebe Standartları/Türkiye Finansal Raporlama Standartları (TMS/TFRS) uygulamalarının mali tablolar oran analizine muhtemel etkilerini ölçmeye yönelik bir çalışma gerçekleştirmiştir. Çalışma sonucunda; standartların finansal oranlar üzerinde farklı etkilerinin olduğu görülmektedir. Bir standardın uygulanması bir oranda artışa neden olurken diğer bir standardın uygulanması aynı oran üzerinde azalışa neden olduğu tespit edilmiştir.

Lainez ve Callao (2000), uluslararası finansal analiz üzerinde muhasebeleştirme farklılığının etkisini ampirik bir çalışma ile yürüttüğü araştırmalarında belirli finansal oranlardan hareketle UFRS'lerin finansal tablolar analizine etkilerini incelemişlerdir. 
Çalışma sonucunda ise, işletmelerin borçlanma oranlarına karşılık likidite oranlarının daha az etkilendiği tespit edilmiştir.

Hope, Jin ve Kang (2005), Daske ve Gebhardt (2006) ve Barth, Landsman ve Lang (2008) ise çalışmalarında; ulusal muhasebe standartlardan Uluslararası Muhasebe Standartları/ Uluslararası Finansal Raporlama Standartları'na geçişle birlikte, finansal rapor kalitesinin etkilendiğini ancak finansal analistler, yatırımcılar ve diğer bilgi kullanıcıları tarafindan kullanılan muhasebe değerleri ve finansal oranlar üzerinde hangi çeşit etkileri olduğunu açıklayamadığı sonucuna varmışlardır.

Petreski (2006), "Firmalar üzerinde Uluslararası Muhasebe Standartlarının Etkisi" başlıklı çalışmasında UFRS'nın finansal tablolar analizine etkilerini incelemiştir. Çalışma sonucunda, UFRS'lerin işletmenin temel finansal tablolarından finansal durum (bilanço) ve faaliyet sonuçları tablosunda (gelir tablosu) önemli değişmelerin gerçekleştiği tespit edilmiş̧tir. UMS/UFRS uygulamalarının özkaynaklarda azalışa, borçlarda ise artışa yol açtığı ortaya çıkmıştır.

Lantto ve Sahlström (2009) çalışmalarında, Finlandiya Muhasebe Standartlarına (FMS) ve UFRS'na göre sunulan finansal tabloların finansal oranlara ilişkin değişimlerini karşılaştırmalı olarak incelemiştir. Finansal kaldıraç oranındaki değişimin borçlanma kalemlerindeki artışa, özkaynak kalemlerinde ise azalışa neden olduğu tespit edilmiştir. Likitide oranlarındaki azalışın nedeni ise, kısa vadeli borçların artmasıdır. Nihai olarak, her iki uygulamada finansal oranların değişmesiyle birlikte, oranların değişmesinde etkili olarak UFRS'ler belirlenerek değişimler açıklanmıştır.

Stent, Bradbury ve Hooks (2010) Yeni Zelanda Borsası'nda işlem gören işletmelerin UFRS'ye geçişi ile birlikte mali tablolar ve oranlar üzerindeki etkilerini araştırmıştır. Çalışma neticesinde, özsermaye karlılığg, varlıkların karlılı̆̆ı, kaldıraç ve satışların getirisi oranlarının her birinin ortancasının arttığını, aktif devir hızı ortancasının ise düştüğünü, ve UFRS'ye geçişle küçük işletmelerin büyük işletmelere göre daha az etkinlediğini tespit etmişlerdir.

\section{3. ÖRNEK UYGULAMA}

Örnek olay uygulamasının ilk kısmında, bir işletmenin TDHP'na göre hazırlanmış finansal tabloları belirli varsayımlar neticesinde bir takım düzeltme ve sınıflandırma kayıtları yapılarak, işletmenin TMS/TFRS'ye göre düzenlenmiş finansal tablolarına ulaşılmıştır. Örnek işletmenin TDHP'na göre hazırlanmış finansal tabloları ile TFRS'ye göre düzenlenmiş finansal tabloları, oluşan farkların tespiti ve finansal tabloların analizi ve yorumlanması açısından karşılaştırmalı olarak sunulmuştur. Çalışma kapsamında, finansal tabloların analizinde en çok kullanılan yöntemlerden biri olan oran analizi yöntemi kullanmıştır. Finansal tablo kalemleri arasında yüzlerce rasyo hesaplanabilir, ancak bu oranlardan faydalı bilgi sağlayan oranların hesaplanması anlamlıdır. Ancak çok sayıda oran hesaplanmaktansa biribiryle anlamlı ilişkiler kurulabilecek finansal tablo kalemleriyle ilgili oranları hesaplamak gerekir (Çabuk ve Lazol, 2009:175). Finansal analizde oranlar yapılacak analizin amacına göre değişmektedir. Bu çalışmada, finansal tabloların işlevleri açısından oranlar; likitide analizi ile ilgili oranlar, finansal yapı analizi ile ilgili oranlar, faaliyet analizi ile ilgili oranlar ve karlılık analizi ile ilgili oranlar olmak üzere 4 grupta ele alınmıştır (Arat, 2005:90-91). Böylece, oran analizi sonuçlarının finansal tabloların TFRS'ye dönüşümünde ne derece etkilendiği tespit edilmeye çalışılmıştır. Karşılaştırmalı olarak sunulan oranların mutlak ve yüzde 
değişimlerinin yorumlanmasında, örnek uygulamadaki verilerin bir ticaret işletmesine ait olduğu kabul edilmiştir. Uygulamada yer alan varsayımlar neticesinde yapılan düzeltme kayıtları özellikle TFRS'ye göre işlem ve sınıflandırma değişimine yol açacak hesaplardan seçilmiştir. Örnek işletmenin TDHP'na göre sunulan temel finansal tabloların, TMS/TFRS'ye uygun hale getirilme süreci işlem içerikleriyle açıklanmış, ve TFRS Finansal Durum ve Faaliyet Sonuçları tablosu düzenlenmiştir. Sonraki bölümde de, TDHP ve TFRS finansal tabloları oran analizi yöntemine tabi tutularak karşılaştırmalı olarak sunulmuş, farklılıklar incelenmiştir.Örnek işletmenin TDHP'na göre hazırlanan ve VUK'nda yer alan değerleme esasları uygulanan finansal tabloları Ek 1 ve Ek 2'de sunulmuştur. İlgili finansal tabloların TFRS'ye dönüştürülmesinde dikkate alınacak değerleme günü işlemleri ise aşağıdaki gibidir:

1. İşletmenin vadeli mevduatlarına $3.000 \mathrm{TL}$ faiz tahakkuk etmiştir.

2. İşletmenin 31 Aralık 2014 tarihi itibariyle menkul kıymet portföyü aşağıdaki gibidir:

\begin{tabular}{|c|c|c|c|c|}
\hline $\begin{array}{c}\text { Hisse } \\
\text { Senedi }\end{array}$ & Maliyet & $\begin{array}{c}\text { Gerçeğe Uygun } \\
\text { Değer } \\
\text { (Borsa Değeri) }\end{array}$ & $\begin{array}{c}\text { İtfa Edilmiş } \\
\text { Maliyet }\end{array}$ & $\begin{array}{c}\text { UMS 39 Kapsamında } \\
\text { Sınıflandırma }\end{array}$ \\
\hline A & 70.000 & 80.000 & --- & Alım Satım Amaçlı \\
\hline B & 50.000 & --- & 60.000 & Vadeye Kadar Elde Tutulacak \\
\hline C & 30.000 & 40.000 & -- & Satılmaya Hazır \\
\hline
\end{tabular}

3. İşletmenin 40.000 TL'lik alacağının vadesi geldiği halde tahsil edilmediği tespit edilmiştir.

4. Ticari alacaklar hesabının etkin faiz yöntemine göre iskonto edilmiş değeri $180.000 \mathrm{TL}$, kayıtlı değeri ise 190.000 TL'dir.

5. Ticari borçların etkin faiz yöntemine göre iskonto edilmiş değeri $210.000 \mathrm{TL}$, kayıtlarda görülen değeri ise $230.000 \mathrm{TL}$ 'dir.

6. Ticari mallar içerisinde 15.000 TL tutarında vadeli alımlardan dolayı fark olduğu tespit edilmiştir.

7. Ticari malların tahmini satış fiyatı $100.000 \mathrm{TL}$ ve tahmini satış gideri ise 7.000TL'dir.

8. $60.000 \mathrm{TL}$ değerindeki makinenin faydalı ömrü 5 yıl olarak belirlenmiştir. Birikmiş amortismanı 10.000 TL olarak kaydedilmiş̧tir. Makinenin işletmeye giriş tarihi 01.04.2014'tür. İşletmede normal amortisman yöntemi baz alınmaktadır.

9. İşletmenin yasal kayıtlarındaki 100.000TL'lik bina bedeline arsa payının da dahil edildiği tespit edilmiştir.Arsa Payı: 50.000 TL ve Birikmiş Amortisman: 5.000 TL'dir.

10. İşletme maliyet değeri $20.000 \mathrm{TL}$ ve birikmiş amortismanı 7.000 TL olan makinesini satmaya karar vermiştir. Makinenin satış giderleri düşülmüş gerçeğe uygun değerinin 10.000 TL olduğu tespit edilmiştir.

11. İşletme $30.000 \mathrm{TL}$ maliyet değerine ve $8.000 \mathrm{TL}$ birikmiş amortismana sahip bir binasını kiraya vermiştir. Binanın gerçeğe uygun değeri 40.000 TL olarak tespit edilmiştir. 
12. İşletmenin genel amaçlı kullandığı kısa vadeli kredi faizinin 4.000 TL'lik kısmı özellikli varlığa aittir.

13. İşletmeye ait Kuruluş ve Örgütlenme giderinin 22.000 TL olarak aktifleştirildiği anlaşılmıştır. Birikmiş amortisman tutarı 8.000 TL'dir.

14. Diğer borçlar incelendiğinde $10.000 \mathrm{TL}$ ilişkili taraflara borç olduğu anlaşılmıştır.

15. Kıdem Tazminatı karşılığı 5.000 TL olarak hesaplanmıştır.

16. 2014 yılı Mart ayında, haksız yere işten çıkarıldığını iddia eden işletme çalışanı işletme aleyhine birikmiş kıdem tazminatı için 6.000 TL tutarında dava açmıştır. İşletme avukatları davayı kaybetme olasılığının \%80 olduğunu belirtmiștir.

17. Ertelenmiş vergi varlığı ve yükümlülüğü hesaplanmıştır.

Düzeltme işlemlerine ilişkin her bir kaydın neden ve hangi amaç ile yapıldığ ilgili standart bazında açıklamalarıyla birlikte Tablo 1'de belirtilmiştir.

Tablo 1: Düzeltme Kayıtları ve İlgili Standartlar ile Birlikte Gerekçeleri

\begin{tabular}{|c|c|c|c|c|c|}
\hline No. & Düzeltme Kayıtla & & & $\begin{array}{c}\text { İlgili } \\
\text { TMS/TFRS }\end{array}$ & Açıklama \\
\hline 1 & $\begin{array}{l}\text { Banka } \\
\qquad \text { Faiz Gelirleri }\end{array}$ & 3.000 & 3.000 & $\begin{array}{l}\text { TMS } 39 \\
\text { TFRS } 9\end{array}$ & $\begin{array}{l}\text { Vadeli mevduatlar "Kredi ve Alacaklar" } \\
\text { olarak yeniden sınıflandırılıp, itfa } \\
\text { edilmiş maliyet ile değerlenir }\end{array}$ \\
\hline 2C & $\begin{array}{l}\text { Hisse Senetleri } \\
\text { Diğer Olağ. Gelir ve Karlar } \\
\text { Hisse Senetleri } \\
\text { Diğer Olağ. Gelir ve Karlar } \\
\text { Diğer Menkul Kıymetler } \\
\quad \text { Hisse Senetleri } \\
\text { Diğer Menkul Kıymetler } \\
\quad \text { Finansal Varlık Değ. Farkları }\end{array}$ & $\begin{array}{l}10.000 \\
30.000 \\
10.000\end{array}$ & $\begin{array}{r}10.000 \\
10.000\end{array}$ & $\begin{array}{l}\text { TMS } 39 \\
\text { TFRS } 7\end{array}$ & $\begin{array}{l}\text { Alım satım amaçlı bir finansal varlık } \\
\text { gerçeğe uygun değerinden ölçülür. } \\
\text { Meydana gelen fark kar veya zarar } \\
\text { olarak gelir tablosuna yansıtılır. } \\
\text { Vadeye kadar elde tutulacak finansal } \\
\text { varlıklar İskonto edilmiş değerinden } \\
\text { ölçülür. Prim ve iskonto farklı gelir } \\
\text { tablosunda gösterilir. } \\
\text { Satılmaya hazır finansal varlıklar } \\
\text { gerçeğe uygun değerinden ölçülür, değer } \\
\text { artış ve azalış farkları hisse senedi } \\
\text { satılana kadar özkaynaklarda izlenir. } \\
\text { Alım-satım amaçlı hisse senetleri mali } \\
\text { duran varlıklar hesabına alınır. }\end{array}$ \\
\hline 3 & $\begin{array}{l}\text { Şüpheli Ticari Alacaklar } \\
\quad \text { Ticari Alacaklar } \\
\text { Karş1lık Giderleri } \\
\\
\text { Şüpheli Ticari Alacak Karş. }\end{array}$ & 40.000 & 40.000 & TMS 39 & $\begin{array}{l}\text { Ticari alacaklar mali tablolarda etkin } \\
\text { faiz yöntemine göre hesaplanmış } \\
\text { iskonto edilmiş bedelleriyle yer } \\
\text { almaktadır. VUK'daki gerekçelerin } \\
\text { yerine gelmesi beklenmeden tahsil } \\
\text { kabiliyeti olmayan her türlü alacak için } \\
\text { şüpheli alacak karş1lığ ayırmak } \\
\text { gerekmektedir. }\end{array}$ \\
\hline 4 & $\begin{array}{l}\text { Reeskont Faiz Gid. } \\
\text { Ticari Alacak Reeskontu } \\
\end{array}$ & 10.000 & 10.000 & TMS 39 & $\begin{array}{l}\text { UMS } 39 \text { 'a göre alacakların tamamı } \\
\text { reeskonta tabidir. Finansal varlığın itfa } \\
\text { edilmiş maliyet değeri, etkin faiz oran } \\
\text { yöntemi ile hesaplanır. }\end{array}$ \\
\hline 5 & $\begin{array}{l}\text { Ticari Borçlar Reeskontu } \\
\text { Reeskont Faiz Gelirleri }\end{array}$ & 20.000 & 20.000 & TMS 39 & $\begin{array}{l}\text { UMS } 39 \text { 'a göre ticari borçlara ilişkin } \\
\text { reeskont işlemi de itfa (iskonto) edilmiş } \\
\text { maliyet değeriyle yansitılır. }\end{array}$ \\
\hline 6 & $\begin{array}{l}\text { Finasman Giderleri } \\
\text { Ticari Mallar }\end{array}$ & 15.000 & 15.000 & TMS 2 & $\begin{array}{l}\text { UMS 2'ye göre vadeli alınan stoklarda } \\
\text { vade farkı stok maliyetine dahil edilmez. } \\
\text { Finanse edildiği dönemin faiz gideri } \\
\text { olarak muhasebeleştirilir. }\end{array}$ \\
\hline
\end{tabular}




\begin{tabular}{|c|c|c|c|c|c|}
\hline 7 & $\begin{array}{l}\text { Karş1lık Giderleri } \\
\text { Stok Değer Düşüklüğü }\end{array}$ & 12.000 & 12.000 & TMS 2 & $\begin{array}{l}\text { Stoklar, maliyet bedeliyle net } \\
\text { gerçeklesebilir değerinden düşük olanı } \\
\text { ile değerlenir. Stokların NGD'i düşük } \\
\text { olduğu için stoklar bu değere indirgenir. }\end{array}$ \\
\hline 8 & $\begin{array}{l}\text { Birikmiş Amortisman } \\
\text { Birikmiş Amortisman } \\
\text { Genel Yönetim Giderleri }\end{array}$ & 10.000 & $\begin{array}{l}9.000 \\
1.000 \\
\end{array}$ & TMS 16 & $\begin{array}{l}\text { Tüm maddi duran varlıklar için kıst } \\
\text { amortisman yöntemi uygulanır. }\end{array}$ \\
\hline 9 & $\begin{array}{l}\text { Arsa ve Araziler } \\
\qquad \text { Binalar } \\
\text { Birikmiş Amortisman } \\
\text { Genel Yönetim Giderleri }\end{array}$ & $\begin{array}{r}50.000 \\
5.000\end{array}$ & 50.000 & TMS 16 & $\begin{array}{l}\text { Arsa payı ayrı hesapta izlenmelidir. Arsa payı } \\
\text { bina maliyetinden düşürülerek, arsa } \\
\text { hesabında izlenir. } \\
\text { Boş arsa ve araziler amortismana tabi } \\
\text { değildir. Binanın arsadan aldı̆̆ pay } \\
\text { düsüldükten sonra amortisman tutarı iptal } \\
\text { edilir. }\end{array}$ \\
\hline 10 & $\begin{array}{l}\text { Satış Amaçlı Duran Varlıklar } \\
\text { Birikmiş Amortisman } \\
\text { Diğer Olağ. Gider ve Zararlar } \\
\text { Tesis Makine ve Cihazlar }\end{array}$ & $\begin{array}{r}10.000 \\
7.000 \\
3.000\end{array}$ & 20.000 & TFRS 5 & $\begin{array}{l}\text { Varlığın hemen satılabilecek durumda } \\
\text { olması ve satış olasılığının da yüksek } \\
\text { olması durumunda, duran varlık defter } \\
\text { değeri ile satış giderleri düşülmüş } \\
\text { gerçeğe uygun değerinden düşük olanı } \\
\text { ile dönen varlıklar içerisine alınır. }\end{array}$ \\
\hline 11 & $\begin{array}{l}\text { Yatırım Amaçlı Gayrimenkuller } \\
\text { Birikmiş Amortisman } \\
\text { Binalar } \\
\text { Diğer Olağan Gelir ve Karlar }\end{array}$ & $\begin{array}{r}40.000 \\
8.000\end{array}$ & $\begin{array}{l}30.000 \\
18.000 \\
\end{array}$ & TMS 40 & $\begin{array}{l}\text { Yatıım amaçlı gayrimenkul olarak } \\
\text { sinıflandırılan varlıklar bilanço tarihi } \\
\text { itibariyle gerçeğe uygun değerleriyle } \\
\text { gösterilirler. }\end{array}$ \\
\hline 12 & $\begin{array}{c}\text { Yapılmakta Olan Yatırımlar } \\
\text { Finansman Giderleri } \\
\end{array}$ & 4.000 & 4.000 & TMS 23 & $\begin{array}{l}\text { Özellikli varlıkların elde edilmesi, inşası } \\
\text { veya üretimi ile doğrudan } \\
\text { ilişkilendirilen borçlanma maliyetleri } \\
\text { varlığın maliyetine dahil edilir. }\end{array}$ \\
\hline 13 & $\begin{array}{l}\text { Genel Yönetim Giderleri } \\
\text { Kuruluş ve Örg. Giderleri } \\
\text { Birikmiş Amortisman- MODV } \\
\text { Genel Yönetim Giderleri } \\
\end{array}$ & $\begin{array}{r}22.000 \\
8.000\end{array}$ & $\begin{array}{r}22.000 \\
8.000 \\
\end{array}$ & TMS 38 & $\begin{array}{l}\text { Maddi olmayan duran varlıklar } \\
\text { içerisinde yer alan Kuruluş ve } \\
\text { Örgütlenme giderleri TFRS'ye göre } \\
\text { aktifleştirilmeyip, doğrudan dönem } \\
\text { gideri olarak dikkate alınmaktadır. }\end{array}$ \\
\hline 14 & $\begin{array}{l}\text { Ortaklara Borçlar } \\
\text { İlişkili Taraflara Borçlar }\end{array}$ & 10.000 & 10.000 & TMS 24 & $\begin{array}{l}\text { İlişkili taraflara olan olan borçların ayrı } \\
\text { bir kalemde gösterilmesi gerekmektedir. }\end{array}$ \\
\hline 15 & $\begin{array}{l}\text { Genel Yönetim Giderleri } \\
\text { Kıdem Tazm Karşılığı } \\
\end{array}$ & 5.000 & 5.000 & TMS 19 & $\begin{array}{l}\text { Kıdem tazminatları için karşılık ayrılır } \\
\text { ve gider yazılır. }\end{array}$ \\
\hline 16 & $\begin{array}{l}\text { Karşılık Giderleri } \\
\text { Diğ. Borç ve Gid. Karş. }\end{array}$ & 6.000 & 6.000 & TMS 37 & $\begin{array}{l}\text { İşletme aleyhine açılan dava nedeniyle } \\
\text { yükümlülük oluşması ihtimali yüksek } \\
\text { olduğu için karşıllı ayrılır. }\end{array}$ \\
\hline 17 & $\begin{array}{l}\text { Ertelenmiş Vergi Varlığı } \\
\text { Ertelenmiş Vergi Yükümlülüğü } \\
\text { Dönem Karı Vergi ve Yas. Yük }\end{array}$ & $\begin{array}{l}21.000 \\
\ddot{\mathrm{u}} \\
\mathrm{k} . \mathrm{K} \text {. }\end{array}$ & $\begin{array}{r}14.200 \\
6.800\end{array}$ & TMS 12 & $\begin{array}{l}\text { Cari dönem vergi karşılığı ile birlikte, } \\
\text { zamanlama farklılıklarından } \\
\begin{array}{l}\text { kaynaklanan ertelenmiş vergiler } \\
\text { hesaplanmaktadır. }\end{array}\end{array}$ \\
\hline
\end{tabular}


Tablo 2: Ertelenen Vergi Varlıkları ve Yükümlülükleri

\begin{tabular}{|l|c|c|}
\hline EVV / EVY Doğuran İşlemler & Ertelenmiş Vergi Varlı̆̆ & Ertelenmiş Vergi Yükümlülüğü \\
\hline Banka Faiz Geliri & & 3,000 \\
\hline Menkul Kıymetler & & 20,000 \\
\hline Şüpheli Ticari Alacak & 40,000 & \\
\hline Ticari Alacak Reeskontu & 10,000 & 20,000 \\
\hline Ticari Borç Reeskontu & & \\
\hline Stok Değer Düşüklüğü & 12,000 & 1,000 \\
\hline Vadeli Alış & 15,000 & 5,000 \\
\hline MDV- Makine Amortisman & & 18,000 \\
\hline MDV - Bina Amortisman & & 4,000 \\
\hline Satış Amaçlı Duran Varlıklar & 3,000 & \\
\hline Yatırım Amaçlı Gayrimenkuller & & $\mathbf{7 1 , 0 0 0}$ \\
\hline Özellikli Varlık & & $\mathbf{1 4 . 2 0 0}$ \\
\hline Kuruluş ve Örgütlenme Giderleri & 14,000 & \\
\hline Kıdem Tazminatı Karşılı̆̆ı & 5,000 & \\
\hline Karşılık Giderleri & 6,000 & $\mathbf{1 0 5 , 0 0 0}$ \\
\hline Toplam & $\% 20$ & \\
\hline & $\mathbf{2 1 . 0 0 0}$ & \\
\hline & 21000 & \\
\hline
\end{tabular}

Oluşan ertelenmiş vergi varlıkları hesabı 21.000 TL borçlandırılırken, ertelenmiş vergi yükümlülükleri hesabı da 14.200 TL alacaklandırılarak, 6.800 TL'lik fark ise dönem kârı vergi ve diğer yasal yükümlülükler hesabının alacağına kaydedilir.

Standart uygulamaları ile vergi uygulamaları arasında değerleme ve sinıflandırma işlemlerinden kaynaklı farklılıklar ortaya çıkmaktadır. Bu farklılıklar neticesinde TMS/TFRS'lere göre hesapanan muhasebe karı ile vergi otoritelerince her hesap dönemi için tespit edilen ve üzerinden vergi ödenen mali kar arasında da farklılıklar oluşmaktadir.

Finansal durum tablosunda (bilançoda) bir varlık veya borç kaleminin defter değeri ile vergi mevzuatına tabi değeri arasında oluşan bu farklar geçici farklardır. Böylece ortaya çıan geçici farklar doğrultusunda ertelenen vergi yükümlülüğü veya ertelenen vergi varlığı oluşmaktadır (KGK, TMS12: Gelir Vergileri).

TDHP'na göre hazırlanan olan finansal tabloların TFRS düzeltme kayıtları neticesinde işletmenin TFRS'ye dönüştürülmüş finansal tablolarına ulaşılmıştır. TMS/TFRS'lere göre düzenlenen finansal tablolar ise $\mathrm{Ek} 3$ ve Ek 4'te sunulmuştur. Bu işlemlerin ardından işletmenin TDHP ve TFRS'ye göre hazırlanmış finansal tablolarına ilişkin oranlar karşılaştırılmalı olarak sunulmuş ve farklılıklara yol açan unsurların tespitine yer verilmiştir. 


\subsection{TDHP-TFRS Finansal Tablolarının Oran Analizi}

İşletmenin TDHP'na göre düzenlenen finansal tabloları ile TFRS'ye dönüştürülmüş finansal tabloları üzerinde oran analizi yapılmıştır. Böylece TFRS uygulamalarına geçisin finansal analiz üzerindeki etkisinin, oran analizi yöntemi ile tespit edilmesi amaçlanmıştır. Çalışmanın finansal analiz kısmında, ulusal ve uluslararası literatürde temel alınan oranlar ele alınarak işletmenin oran analizini likitide, faaliyet, finansal yapı ve karlılık açısından karşılaştırmak üzere toplam 15 adet oran kullanılmıştır. Her bir oran, bilanço ve gelir tablosundan elde edilen farklı hesap gruplarını temsil etmektedir. Seçilen oranlarla, finansal tabloların TFRS'ye dönüşümünde hangi standart uygulamaları kapsamında oran analizi sonuçlarının etkilendiği tespit edilmeye çalış1lmıştır.

Tablo 3: TDHP ve TFRS Finansal Tablolarının Karşılaştırmalı Oran Analizi

\begin{tabular}{|c|c|c|c|c|c|}
\hline Grup & Oranlar & Formüller & TDHP & TMS/TFRS & \% Değişim \\
\hline \multirow{3}{*}{$\begin{array}{l}\text { Likitide } \\
\text { Oranları }\end{array}$} & Cari Oran & $\frac{\text { Dönen Varlıklar }}{\text { Kısa Vadeli Yabancı Kaynaklar }}$ & 1.78 & 1.62 & $-9.16 \%$ \\
\hline & Asit-Test Oranı & $\underset{\text { Kısa Vadeli Yabancı Kaynaklar }}{\stackrel{\text { Dönen Varlıklar-Stoklar }}{\text { Vaden }}}$ & 1.40 & 1.31 & $-6.51 \%$ \\
\hline & Nakit Oran & $\frac{\text { Hazır Değerler+Menkul Kıymetler }}{\text { Kısa Vadeli Yabancı Kaynaklar }}$ & 0.67 & 0.68 & $1.18 \%$ \\
\hline \multirow{4}{*}{$\begin{array}{l}\text { Faaliyet } \\
\text { Oranları }\end{array}$} & Stok Devir Hizı & $\frac{\text { Satılan Malın Maliyeti }}{\text { Ticari Mallar }}$ & 3.00 & 3.43 & $14.29 \%$ \\
\hline & Alacak Devir Hızı & $\underset{\text { Ticari Alacaklar }}{\stackrel{\text { Net Satıslar }}{\text { Ticaki }}}$ & 3.37 & 4.08 & $21.05 \%$ \\
\hline & Aktif Devir Hızı & $\frac{\text { Net Satıslar }}{\text { Aktif Toplamı }}$ & 1.02 & 1.03 & $1.60 \%$ \\
\hline & Duran Varlık Devir Hızı & Maddi Duran Varlıklar (Net) & 4.12 & 4.75 & $15.29 \%$ \\
\hline \multirow{4}{*}{$\begin{array}{l}\text { Finansal } \\
\text { Yapı } \\
\text { Oranları }\end{array}$} & Kaldıraç Oranı & $\frac{\text { Yabancı Kaynaklar }}{\text { Aktif Toplamı }}$ & 0.44 & 0.45 & $3.19 \%$ \\
\hline & Uzun Vadeli Borç Oranı & $\begin{array}{c}\frac{\text { Uzun Vadeli Yabanc1 Kaynaklar }}{\text { Uzun Vadeli Yabancı Kaynaklar }}+ \\
\text { Özkaynaklar }\end{array}$ & 0.04 & 0.08 & $100.16 \%$ \\
\hline & İmmobilizasyon Oranı & $\frac{\text { Duran Varlıklar }}{\text { Özkaynaklar }}$ & 0.47 & 0.64 & $36.17 \%$ \\
\hline & Borçlanma Katsayısı & $\frac{\text { Yabancı Kaynaklar }}{\text { Özkaynaklar }}$ & 0.78 & 0.82 & $5.13 \%$ \\
\hline
\end{tabular}




\begin{tabular}{|c|c|c|c|c|c|}
\hline \multirow{4}{*}{$\begin{array}{l}\text { Karlılık } \\
\text { Oranları }\end{array}$} & Satı̧ Karlıl1k Oranı & $\begin{array}{l}\text { Net Kar } \\
\text { Net Satışlar }\end{array}$ & 0.19 & 0.16 & $-18.13 \%$ \\
\hline & Aktif Karlılık Oranı & $\stackrel{\text { Net Kar }}{\text { Toplam Varlıklar }}$ & 0.20 & 0.16 & $-16.82 \%$ \\
\hline & Özkaynak Karlıl1k Oranı & $\underset{\text { Özkaynaklar }}{\frac{\text { Net Kar }}{k a y n a}}$ & 0.35 & 0.30 & $-14.71 \%$ \\
\hline & Faaliyet Karlıl1k Oranı & $\frac{\text { Toplam Varlıklar }}{\text { Özkaynaklar }}$ & 1.78 & 1.82 & $2.54 \%$ \\
\hline
\end{tabular}

\subsubsection{Likitide Oranları}

Likitide oranları; nakit elde etme kolaylığını ve kısa vadeli borçlarını ödeme gücünü gösteren oranlardır (Savc1, 2017: 192) İşletmenin TDHP ve TFRS mali tablolarına ilişkin likitide oranlarında büyük ölçüde değişim olmamıştır. Ancak TFRS'ye göre likitide oranları daha düşük çıkmıştır. Dönen varlıklar ve kısa vadeli yabancı kaynaklarda önemli ölçüde değişiklik olmamakla birlikte işletmenin TFRS mali tablolarındaki net çalışması sermayesinin düştügü tespit edilmiştir. Dönen varlıklardaki değişimin nedenleri, vadeli mevduatın itfa edilmiş maliyet değeri üzerinden yansıtılması, hisse senetlerindeki sınıflandırma farklılıkları, şüpheli hale gelmiş alacaklara karşılık ayrılması, ticari alacakların reeskonta tabi tutulması stoklar içerisindeki vade farkının ayrıştırılması, ve stoklar net gerçekleşebilir değerine indirgenmesidir. Değişime neden olan bu işlemlerin yanı sıra işletme makineyi bir yıl içerisinde satma kararı verdiği için ilgili duran varlık dönen varlıklar hesap grubuna aktarılmış, ancak mutlak değer olarak düşük olduğu için likitide oranlarını önemli ölçüde etkilememiştir. Kısa vadeli yabancı kaynaklarda ise ticari borçlara uygulanan reeskont işleminden dolayı azalış söz konusudur.

\subsubsection{Faaliyet Oranları}

Faaliyet oranları; işletmenin varlıklarının ne derecede etkin kullanıp kulanılmadığını gösteren oranlardır (Savc1, 2017: 191). UFRS'ye göre duzenlenen finansal tablolarda özellikle faaliyet oranları değişim gösteren oran grubudur. Duran varlıkların sınıflandırma farkından kaynaklı olarak duran varlık devir hızı \%15 değişim göstermiştir. TFRS'ye göre yapılan düzeltmeler neticesinde stoklardan vade farkının düşürülmesi ve değer düşüklüğüne uğraması stok devir hızını önemli ölçüde etkilemiştir. Ticari alacakların reeskonta tabi tutularak iskonto edilmiş değerleri ile gösterilmesi ve şüpheli alacak karşılıklarının ayrılması TFRS tablolarında ticari alacaklar tutarını düşürdüğünden dolayı alacak devir hızı daha yüksek çıkmıştır. Aktif devir hızı ise her iki düzenlemede benzer oranlara sahiptir. Aktif toplamındaki azalışın nedeni, kredili mevduat hesabındaki değişim, ticari alacakların itfa edilmiş maliyet değerine indirgenmesi, şüpheli ticari alacak karşılı̆̆ 1 , stoklardan finansman giderlerinin çıkarılması ve değer düşüklüğüne uğraması, maddi duran varlıklar için kıst amortisman uygulaması, kuruluş ve örgütlenme giderlerinin aktifleştirilmeyip doğrudan gider yazılmasidir. 


\subsubsection{Finansal Yapı Oranları}

İşletmenin finansal yapısını ortaya koyarak uzun vadeli borç ödeme gücünü gösteren oranlardır (Savc1, 2017: 195). Finansal yapı oranlarının TFRS finansal tablolarında değişim göstermesinin nedeni, TFRS'ye göre yabancı kaynak toplamındaki artış neticesinde, aktif toplamında azalış gerçekleşmesinden kaynaklıdır. Kısa vadeli yabancı kaynaklardaki azalışın nedeni ise borçların iskonto edilmesidir. UMS 37 kapsamında ayrılan karşılıkların uzun vadeli yabancı kaynaklar hesap grubunda borç ve gider karşılıkları olarak raporlanması uzun vadeli borç oranında artışa sebep olmuştur. İmmobilizasyon oranındaki değişimin nedeni TFRS düzeltme kayıtları neticesinde maddi duran varlıklardaki artıştır. Ayrıca değerleme farklılıkları sonucu muhasebe değeri ve vergi değerindeki fark ertelenmiş vergi varlığı olarak duran varlıklar hesap grubuna eklenmiştir. Duran varlıklarda sınıflandırılan hisse senetlerinin gerçeğe uygun değerindeki artış, finansal varlık değerleme farkı olarak özkaynaklarda raporlanmıştır. TMS 38 Maddi Olmayan Duran Varlıklar standardı uyarınca, aktifleştirilen kuruluş ve örgütlenme giderleri doğrudan gider olarak yazılmıştır. Bu doğrultuda dönem net karı azalmış, bu azalış neticesinde özkaynaklar hesap grubu düşüş göstermiştir. Borçlanma katsayısı rasyosu, dönem karından kaynaklı özkaynaklardaki azalış ile birlikte yabancı kaynaklarda artış olması nedeniyle TFRS finansal oranlarında daha yüksek olduğu görülmektedir. Özkaynaklardaki azalışın nedeni, dönem net karındaki azalıştan kaynaklanmaktadır.

\subsubsection{Karlılık Oranları}

İşletmenin faaliyet sonuçlarının başarı olup olmadığını gösteren oranlardır (Savcı, 2017: 191). İşletmenin TDHP ve TFRS finansal tablolarına ilişkin karlılık oranlarında mutlak değer olarak önemli ölçüde değişim olmamıştır. TFRS düzeltmeleri kayıtları neticesinde faaliyet karı tutarındaki azalış ile birlikte, finansman giderindeki artış, karşılık giderlerinin doğması, reeskont giderlerindeki artış dönem net karını etkilemiştir. Dönem net karındaki azalma nedeniyle satış karlılığ $\% 18$ 'lik, aktif karlılık oranı \%16'lık bir düşüş göstermiştir. Özkaynak karlılık oranındaki değişimin nedeni ise dönem net karındaki azalıştan kaynaklı olarak özkaynakların etkilenmesidir. Faaliyet karının net satıslara oranındaki azalış, faaliyet karının genel yönetim giderlerindeki artıştan etkilenmesidir. kuruluş ve örgütlenme harcamalarının gider olarak kaydedilmesi ve kıdem tazminatı karşılığı ayrılması genel yönetim giderlerinin artmasına neden olmuştur.

\section{SONUÇ}

Türkiye Muhasebe ve Finansal raporlama standartlarına uygun hale getirilen finansal tablolar, finansal analiz açısından bazı değişimleri beraberinde getirmektedir. Özellikle, hesap kalemlerine ait değerleme esasları ile birlikte hesap tutarı ve sınıflandırmasında önemli değişimler mevcuttur. TMS/TFRS uygulamaları ile birlikte, mevcut hesap planında bulunmayan ticari alacak ve borç reeskontu, stok değer düşüklüğü, ertelenmiş vergi yükümlülüğü ve ertelenmiş vergi varlığ gibi farklı nitelik ve işleme sahip hesap kalemlerinin kullanımı söz konusudur.

TDHP'na göre düzenlemiş finansal tabloların TFRS'ye dönüştürülmesinde dikkate alınacak değerleme günü işlemleri neticesinde yapılan düzeltme kayıtları işletmenin varlık, yülümlülük ve kar/zarar tutarlarının değişimine sebep olmaktadır. Finansal raporlamadaki değerleme ve sınıflandırma farklılıkları şüphesiz ki finansal analiz 
sonuçlarını da etkilemiştir. Bu çalışma kapsamında kullanılan oran analizi yöntemine ilişkin değişim gösteren oranların, hangi standart uygulamaları neticesinde farklılık gösterdiği tespit edilmeye çalışılmıştır.

TMS/TFRS'ye geçişin finansal analiz üzerindeki etkisini olumlu ya da olumsuz olarak analiz etmekten ziyade, oranlardaki değişime sebep olan hesap kalemlerine ilişkin hangi standart uygulaması kapsamında düzeltme kayıtlarının yapıldığını tespit etmek daha uygun olacaktır. Sonuç olarak, örnek uygulama kapsamında; dönen varlıklardan stoklara ait vade farkının ayrıştırılması, TMS/TFRS'lere göre finansman gideri olarak raporlanması ve stok değer düşüklüğü karşılığı ayrılması, ticari alacakların reeskonta tabi tutulması, kuruluş ve örgütlenme giderlerinin aktifleştirilmeyip doğrudan gider yazılması dönen varlık tutarının değişmesine, ve analiz sonuçlarının farklılaşmasına sebebiyet vermiştir. Ticari borçların reeskonta tabi tutulması ve borç ve gider karşılıkları neticesinde kısa vadeli yabancı kaynaklar hesap grubunun etkilenmesinin likitide oran sonuçlarını etkilediği gözlemlenmiştir. Dönem net karının, kıdem tazminatı gibi karşılık giderleri ve reeskont giderlerinden etkilenmesi sonucu karlılık oranlarının değiştiği görülmektedir. Yapılan oran analizi sonuçları, muhasebe standartlarının oranları farklı yönde etkilediğini göstermektedir. $\mathrm{Bu}$ çalışma, sektör bazında sektör oranları ile karşılaştırmalı olarak, ya da farklı yıllar itibariyle TDHP ve TFRS finansal tablo oranları kıyaslanarak değişimin yönü doğrutusunda farklı çalışmalar ile geniş̧letilebilir.

\section{KAYNAKÇA}

Ağca,A.\&Aktaş, R. (2007).First time application of IFRS and its impact on financial ratios: A study on Turkish listed firms. Problems and Perspectives in Management, $5(2), 99$.

Akdoğan, N.\&Tenker, N. (2007). Finansal Tablolar ve Mali Analiz Teknikleri. Ankara: Gazi Kitabevi.

Alkan, G.İ.\&Doğan, O. (2012). Uluslararası Finansal Raporlama Standartlarının Finansal Rasyolara Kısa ve Uzun Dönemli Etkileri: Borsa İstanbul'da bir Araştırma, Muhasebe ve Finansman Dergisi:87-100.

Arat, M. E. (2005). Finansal Analiz Aracı Olarak Oranlar: İlkeler ve Yorumlar, Marmara Universitesi Nihad Sayar Eğitim Vakfi, İstanbul.

Ataman, B.\&Özden, E.A. (2009). Tek Düzen Hesap Planına Göre Hazırlanan Finansal Tabloların UFRS'ye Uyarlanması ve Rasyo Yöntemi ile Analizi, Muhasebe Finansman Dergisi, 44,59-73.

Atmaca, M. (2010). Uluslararası muhasebe ve finansal raporlama standartlarının işletmelerin finansal analizine etkilerini değerlendirmeye yönelik bir araştırma, Marmara Üniversitesi İ̈BF Dergisi, 28(1), 523-548.

Balcı, B.Z. (2012).TFRS'lerin Oran Analizine Etkileri, Journal of Yasar University, 28(7),4687 - 4707.

Bayir, O. (2010). Tekdüzen Muhasebe Sistemine ve Türkiye Muhasebe - Finansal Raporlama Standartlarına göre Bilançonun Biçimsel Yapısı, Kapsamı ve İçeriğinin Karşılaştırmalı Analizi, Mali Çözüm Dergisi,(98), 89-116. 
Büyükşalvarc1, A. \& Uyar, S. (2012). Farklı Muhasebe Düzenlemelerine Göre Hazırlanan Mali Tablolardan Elde Edilen Finansal Oranlar İle Şirketlerin Hisse Senedi Getirileri ve Piyasa Değerleri Arasındaki İlişki, Muhasebe ve Finansman Dergisi, (53), 25-48.

Çabuk, A. ve Lazol, İ. (2009). Mali Tablolar Analizi, 8. Baskı, Bursa: Ekin Yayınevi.

Çelik, M., Aygören, H. ve Uyar, S. (2007). The Impact of international financial reporting standards on financial statement and financial ratios", The Balkan Countries

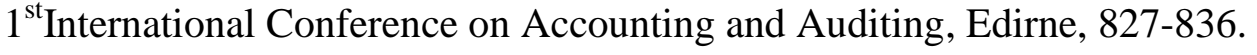

Elitaş, C. (2010). Türkiye Muhasebe Standartları/Türkiye Finansal raporlama Standartlarının Benimsenmesinin Bazı Temel Finansal Oranlar Üzerindeki Etkisi Üzerine Uygulamalı Bir Değerlendirme, Muhasebe ve Denetime Bakış, (30),57-68.

Hope vd. (2005). Empirical Evidence on Jurisdictions that Adopt IFRS, Journal of International Accounting Research. 5,1-20.

Lainez,J.A.\&Callao,S.(2000). The Effect of Accounting Diversity on International Financial Analysis: Empirical Evidence, The International Journal of Accounting, 35 (1), 65-83.

Lantto, A.M. \& Salstrom,P.(2009).Impact of international financial reporting standard adoption on key financial ratios, Account and Finance, (49),341-361.

Petreski, M. (2006). The Impact of International Accounting Standards on Firms. Financial Accounting and Reporting Section Meeting Paper, 1-12.

Stent, W., Bradbury, M. \& Hooks, JILL (2010), IFRS in New Zealand: Effects on Financial Statements and Ratios, Pacific Accounting Review, 22(2), 92-107.

Terzi, S.,Oktem, R.\&Sen, İ.K. (2013), Impact of Adopting International Financial Reporting Standards:Empirical Evidence fromTurkey", International Business Research, 6(4),55-66.

Resmi Gazete (2006). 26122 Sayılı Gelir Vergilerine İlişkin Türkiye Muhasebe Standardı (TMS 12) Hakkında Tebliğ, www.kgk.gov.tr adresinden erişildi.

Savcı, M. (2017). Mali Tablolar Analizi Ekin Yayınevi: 7.Baskı, Bursa: Ekin Yayınevi

Sultanoğlu, B. (2014). UFRS'nin Borsa İstanbul'daki Şirketlerin Finansal Tabloları üzerindeki etkisi: Finansal Bilginin Ihtiyaca Uygunluğu ve Finansal Tablolar Analizi, Doktora Tezi, Başkent Üniversitesi: Ankara

Yenigün, T.\&Aydemir, O. (2015). TMS/TFRS Uygulamalarının Oran Analizine Muhtemel Etkileri”, Muhasebe ve Finansman Dergisi, Ocak, 63-80. 
EK 1:

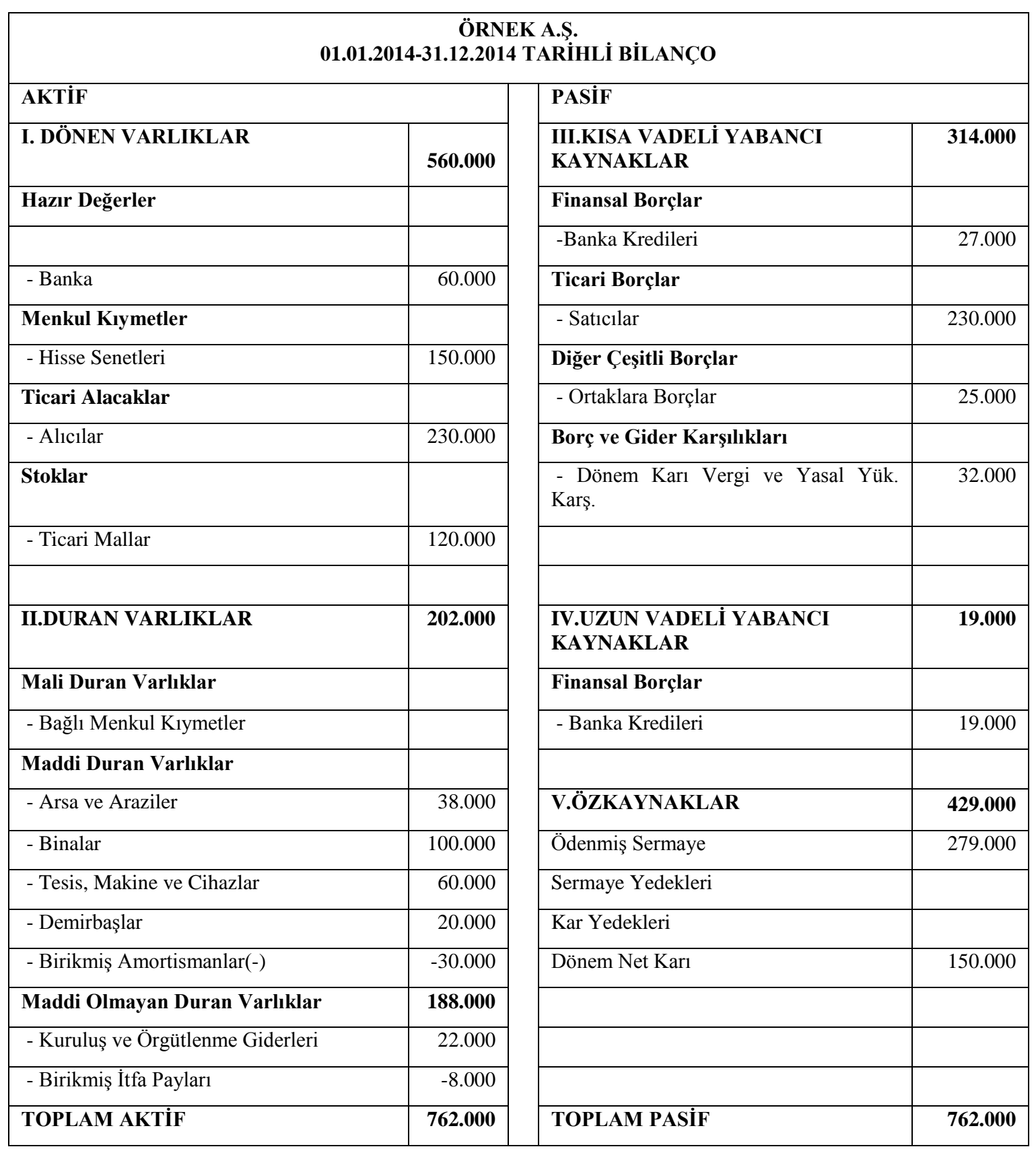


EK 2:

\begin{tabular}{|c|c|}
\hline 01.0 & \\
\hline BRÜT SATIŞLAR & \\
\hline - Yurtiçi Satışlar & 810.000 \\
\hline SATIŞ İNDİRIMLERI & \\
\hline - Satış İadeleri & -16.000 \\
\hline - Satı̧ı İskontoları & -19.000 \\
\hline NET SATIŞLAR & 775.000 \\
\hline SATIŞLARIN MALIYYETİ & \\
\hline - Satılan Malın Maliyeti & -360.000 \\
\hline BRÜT SATIŞ KARI & 415.000 \\
\hline FAALIYYET GİDERLERİ & \\
\hline - Pazarlama Satış ve Dağıtım Giderleri & -98.000 \\
\hline - Genel Yönetim Giderleri & -124.000 \\
\hline FAALIYYT KARI & 193.000 \\
\hline DİĞER FAAL. OLAĞAN GELİR VE KAR & \\
\hline - Faiz Gelirleri & 11.000 \\
\hline - Diğer Olağan Gelir ve Karlar & 5.000 \\
\hline DİĞER FAAL. OLAĞAN GİDER VE ZAR & \\
\hline - Diğer Olağan Gider ve Zararlar & -14.000 \\
\hline FINANSMAN GIIDERLERİ & -13.000 \\
\hline DÖNEM KARI & 182.000 \\
\hline Dönem Karı Vergi ve Yasal Yük. Karşılıkları & 32.000 \\
\hline DÖNEM NET KARI & 150.000 \\
\hline
\end{tabular}


EK 3:

\begin{tabular}{|c|c|c|c|}
\hline \multicolumn{4}{|c|}{$\begin{array}{l}\text { ÖRNEK A.Ş. } \\
\text { 01.01.2014-31.12.2014 TARİHLİ FİNANSAL DURUM TABLOSU }\end{array}$} \\
\hline \multicolumn{2}{|l|}{ VARLIKLAR } & \multicolumn{2}{|l|}{ KAYNAKLAR } \\
\hline DÖNEN VARLIKLAR & 486.000 & KISA VADELİ YÜKÜMLÜLÜKLER & 300.000 \\
\hline Nakit ve Nakit Benzerleri & & Kısa Vadeli Borçlanmalar & \\
\hline - Banka & 63.000 & -Banka Kredileri & 27.000 \\
\hline Finansal Yatırımlar & & Ticari Borçlar & \\
\hline - Hisse Senetleri & 140.000 & - Satıcilar & 230.000 \\
\hline Ticari Alacaklar & & - Ticari Borçlar Reeskontu & -20.000 \\
\hline - Alıcilar & 190.000 & Diğer Çeşitli Borçlar & \\
\hline - Şüpheli Ticari Alacak & 40.000 & - Ortaklara Borçlar & 15.000 \\
\hline - Şüpheli Ticari Alacak Karşıllğı & -40.000 & - İlişkili Taraflara Borçlar & 10.000 \\
\hline - Ticari Alacak Reeskontu & -10.000 & $\begin{array}{l}\text { Dönem Karı } \\
\text { Yükümlülüğ̈̈ }\end{array}$ & 32.000 \\
\hline Stoklar & & Kısa Vadeli Karşılıklar & \\
\hline - Ticari Mallar & 105.000 & - Diğer Borç ve Gider Karşılıkları & 6.000 \\
\hline - Stok Değer Düşüklüğü Karş1lığ1 & -12.000 & & \\
\hline $\begin{array}{l}\text { Satış Amaçlı } \\
\text { Varlıklar }\end{array}$ & 10.000 & & \\
\hline & & UZUN VADELİ YÜKÜMLÜLÜKLER & 38.200 \\
\hline DURAN VARLIKLAR & 264.000 & Uzun Vadeli Borçlanmalar & \\
\hline Finansal Yatırımlar & & - Banka Kredileri & 19.000 \\
\hline - Diğer Menkul Kiymetler & 40.000 & Uzun Vadeli Karşılıklar & \\
\hline Yatırım Amaçlı Gayrimenkuller & 40.000 & Kıdem Tazminatı Karşılığ1 & 5.000 \\
\hline Maddi Duran Varlıklar & & Ertelenmiş Vergi Yükümlülüğüü & 14.200 \\
\hline - Arsa ve Araziler & 88.000 & & \\
\hline - Binalar & 20.000 & & \\
\hline - Tesis, Makine ve Cihazlar & 40.000 & ÖZKAYNAKLAR & 411.800 \\
\hline - Demirbaşlar & 20.000 & Ödenmiş Sermaye & 279.000 \\
\hline - Birikmiş Amortismanlar(-) & -9.000 & Sermaye Yedekleri & \\
\hline - Yapılmakta Olan Yatırımlar & 4.000 & - Finansal Varlık Değerleme Fonu & 10.000 \\
\hline Ertelenmiş Vergi Varlığı & 21.000 & Dönem Net Karı & 122.800 \\
\hline TOPLAM AKTİF & 750.000 & TOPLAM PASİF & 750.000 \\
\hline
\end{tabular}


EK 4:

\begin{tabular}{|c|c|}
\hline \multicolumn{2}{|c|}{$\begin{array}{c}\text { ÖRNEK A.Ş. } \\
\text { 01.01.2014 - 31.12.2014 KAR-ZARAR ve KAPSAMLI GELİR TABLOSU }\end{array}$} \\
\hline Hasılat & 775.000 \\
\hline Satışların Maliyeti (-) & -360.000 \\
\hline Brüt Kar/Zarar & 415.000 \\
\hline Genel Yönetim Giderleri & -137.000 \\
\hline Pazarlama Satış ve Dağıtım Giderleri & -98.000 \\
\hline Esas Faaliyet Karı/Zararı & 180.000 \\
\hline \multicolumn{2}{|l|}{ Diğer Faaliyetlerden Olağan Gelir ve Karlar } \\
\hline - Faiz Gelirleri & 14.000 \\
\hline - Diğer Olağan Gelir ve Karlar & 43.000 \\
\hline - Reeskont Faiz Geliri & 20.000 \\
\hline \multicolumn{2}{|l|}{ Diğer Faaliyetlerden Olağan Gider ve Zararlar } \\
\hline - Diğer Olağan Gider ve Zararlar & -17.000 \\
\hline - Karşılık Giderleri & -58.000 \\
\hline - Reeskont Faiz Gideri & -10.000 \\
\hline FİNANSMAN GİDERİ ÖNCESİ FAALIYYET KARI & $\mathbf{1 7 2 . 0 0 0}$ \\
\hline Finansman Giderleri (-) & -24.000 \\
\hline SÜRDÜRÜLEN FAALIYYETLER VERGİ ÖNCESİ KARI & 148.000 \\
\hline Dönem Vergi Gideri & -32.000 \\
\hline Ertelenen Vergi Etkisi & 6.800 \\
\hline DÖNEM NET KARI & 122.800 \\
\hline
\end{tabular}

